pages, which discuss the subject of anthropology since 1935 .

The section on prehistory and technology in the old World, pp. 345-375, records considerable progress in Near-Eastern archrology since 1935, gives an account of the titles of the main works concerned and sometimes adds a few sentences indicating the general nature of their contents. There are interesting accounts of methods employed in dating archæological discoveries. The author only lapses into speculation, however, when he suggests that, if all modern inventions were lost, those made in the Near Fast about the fifth millennium would still make the good life possible, and when he asserts that prehistoric art was done partly for art's sake and partly to aid the artists to control the incalculable in life.

There follows a survey of physical anthropology since 1935 written by J. S. Weiner (pp. 376-412). Weiner mentions, among other matters, that it still remains for the physical anthropologist to demonstrate in the field how the biological properties of a community and its social organization are interrelated. He tends to over-emphasize the comparative importance of the study of discontinuous variation, on the grounds that the gene systems underlying blood groups are known, whereas the study of continuous variation by 'traditional' anthropometric measures uses phenotypic criteria the genetic bases of which are unknown.

Miss Beatrice Blackwood gives an account of Americanist studies (pp. 412-40), which is adequate except that it omits sociological and psychological studies of the American Indian from review, and refers the reader to a bibliographical paper published elsewhere for titles of such studies.

The final fifteen pages of text on general ethnology and social anthropology list some titles of books, and lay disproportionate stress upon such purely occasional papers as a bibliographical Americanist paper by Betty Meggers and a chapter in "The Development of Scientific Thought in the Twentieth Century", edited by A. E. Heath, by Meyer Fortes. The works of Margaret Mead, which are internationally known for their value, are not mentioned. Otherwise these pages are mainly concerned with a difference of opinion of small importance between Radcliffe-Brown and Evans-Pritchard. RadcliffeBrown considers that sociology will yet become a natural science; Evans-Pritchard points to an absence of laws of social organization discovered to date, represents himself as a "functionalist seeking a new orientation", and in common with RadcliffeBrown ignores the possibility of knowledge of social psychology. There is a long résumé of a single lecture by Evans-Pritchard, but the works of Peristiany, Nadel, Gluckman, Hunter, Kuper, Godfrey Wilson, Hallowell, Embree, Oliver and many others are completely overlooked. Since there is no evidence of similar loss of proportion or failure of good judgment in the preceding three sections of the book reviewed, the author's more than ordinary concern here that the works of a few persons now or recently at Oxford should be given such prominence is all the more remarkable. The result is not a judicious appraisal.

About psychological studies, it has been said that anthropologists who discuss topics of the nature of motivations and attitudes attempt to explain social phenomena in terms of individual psychology; but the social anthropologist and the psychologist study different kinds of phenomena - the former social systems, and the latter psychical systems-and what one studies cannot be understood in terms of conclusions reached by the other. It has also been said that those who study topics of the nature of motives and attitudes avoid the real work of ethnology as drastically as those who study nothing but social organization, and explain what they study in terms of the functional efficiency of organization in maintaining itself. These criticisms are actually not substantial, since knowledge of any still-existing society depends absolutely upon knowledge of individuals who are in that society or who share that culture. The ethnological or social anthropologist critic owes his own knowledge of still-existing peoples to the study of individuals in disregard of antitheses between individual and society, organism and environment, personality and social structure, at least until the last minute when he begins to write down what knowledge he possesses. R. F. FortunE

\section{EXPERIMENTAL METHODS IN ARABLE HUSBANDRY}

The Practice of Arable Crop Experimentation By P. N. Harvey. Pp. vii+79. (Norwich : Norfolk Agricultural Station, Sprowston, 1952.) $6 s$.

$\mathrm{N}$ the literature of agricultural experimentation the 1 statisticians are much more in evidence than the field workers; but no matter how ingenious and adequate statistical methods may be, their practical value in dealing with agricultural problems largely depends on the common sense and skill of those who handle the experimental operations on the farm. As soon as crop trials became something more than rough yield comparisons between treated and untreated halves of the same field, some sort of technique became necessary, and this has been developed during the past thirty years both to meet the needs of the newer experimental designs and to reduce working errors. The people responsible for this have been the field supervisors and farm managers of experimental farms, with the statistician available to advise on matters of principle. The methods developed, although recorded in scattered memoranda and papers, have not been widely published, and it is here that Mr. P. N. Harvey's book makes a useful addition to the literature.

The Norfolk Agricultural Station at Sprowston was well established when the new experimental designs began to be introduced in the early 'twenties, and it was quick to adopt them in its studies of crop husbandry. Mr. Harvey puts on record the field methods that have been gradually built up and developed at the Station for experiments on arable crops. The operations are described in detail with the drawings that are necessary to make the procedure intelligible. The subject-matter covers the choosing of land, the marking out and sowing of plots, and the harvesting and sampling of cereals and roots. The procedure adopted for harvesting plots by combine, a recent development of great promise, is dealt with at length. There are also sections dealing with the application of fertilizers and the calibration of seed and manure drills.

There is no finality in these methods, and field experimenters, now an increasing company, are recommended to read this book, for it will provide a basis on which to review and, in many instances, to improve their own procedure. For students it is an excellent introduction to the subject. 